\title{
DIAGRAMS AND TABLES
}

\author{
Diagram
}

Diagram 1. Relationship Among Frames

TABLES

Table 1. Argentine Historical Frames Central to the Struggle for Human Rights

Table 2. The Historical Human Rights Organizations in Argentina

Table 3. Women's Participation in the Argentine Historical Human Rights Organizations

Table 4. Human Rights Organizations' Willingness to Work with the Government

Table 5. Family Members Emphasized in Collective Action Frames of Affected Human Rights Organizations

Table 6. Impact of the Amnesty Laws and Pardons

Table 7. Increased Use of Roadblocks, 1997-2002

Table 8. Increase in General Strikes, Alfonsín to De la Rúa

Table 9. Images of Argentine Institutions

Table 10. Página/12 Coverage of Affected Human Rights Organizations from September 2000 to June 2001

Table 11. Página/12 Coverage of Solidarity Human Rights Organizations from September 2000 to June 2001 
